\title{
Effect of antibiotics and BAU-biofungicide in controlling bacterial leaf blight of litchi
}

\begin{abstract}
The experiment was carried out in the net house, Department of Plant Pathology, Bangladesh Agricultural University (BAU), Mymensingh, Bangladesh during 16 July 2012 to June 2013 to find out the suitable management practices for controlling bacterial leaf blight of litchi by applying six treatments viz., (i) T1-Gentamycin @ 0.05\%, (ii) T2- Erithromycin@ 0.05\%, (iii) T3-Doxycycline @ 0.05\%, (iv) T4-Copper sulphate @ 0.05\%, (v) T5-BAUbiofungicide @ 2\% and (vi) T6-Control. Per cent incidence and per cent severity have been found to decrease by applying BAU-biofungicide, copper sulphate and gentamycin, although other treatments showed good result in decreasing severity of bacterial leaf blight. BAUbiofungicide was found superior among the treatments as it increased $18.83 \%$ plant height, $43.50 \%$ branch over control and reduced $17.16 \%$ disease incidence and $63.03 \%$ disease severity over control when applied as foliar spray @ 2\%. Copper sulphate reduced $13.85 \%$ disease incidence and $50.21 \%$ disease severity over control and graded second best control measure for bacterial leaf blight of litchi when applied as foliar spray @ 0.05\%.
\end{abstract}

Keyword: Antibiotics; Bacterial leaf blight; Biofungicides; Litchi (Litchi chinensis) 